\title{
Willingness to pay for excreta pellet fertilizer: Empirical evidence from Ghana
}

\author{
John K. M. KUWORNU ${ }^{\mathrm{a}}$, Alfred B. NARH JNR ${ }^{\mathrm{b}}$, Irene S. EGYIR ${ }^{\mathrm{b}}$, Edward E. ONUMAH ${ }^{\mathrm{b}}$, Solomie \\ GEBREZGABHER $^{\mathrm{c}}$
}

Received December 01, 2016; accepted May 04, 2017.

Delo je prispelo 01. decembra 2016, sprejeto 04. maja 2017.

\begin{abstract}
This study examined farmers' willingness to pay for excreta pellet fertilizer in Ghana. Primary data was obtained from 461 farmers in 10 districts in the Western and Greater Accra regions of Ghana through randomized questionnaire administration. The contingent valuation method was used in eliciting the farmers' willingness to pay decisions (WTP) and maximum amount they were willing to pay. The Tobit regression model results revealed that being a household head, unit cost of current fertilizer used, and farm size positively influenced the willingness to pay amount whereas previous use of organic fertilizer influenced the willingness to pay amount negatively. These results have implications for marketing of excreta pellet as fertilizer in Ghana.
\end{abstract}

Key words: excreta pellet fertilizer; farmers; willingness to pay; Tobit regression; Ghana

\section{IZVLEČEK}

\section{PRIPRAVLJENOST ZA NAKUP GNOJILNIH PELET IZ FEKALIJ: EMPIRIČNI PRIMER IZ GANE}

Raziskava analizira pripravljenost kmetov za nakup gnojilnih pelet iz fekalij v Gani. Osnovni podatki so bili pridobljeni od 461 kmetov $\mathrm{z}$ naključnim vprašalnikom iz 10 okrožij $\mathrm{v}$ zahodnem in širšem območju Akre. Za ovrednotenje pripravljenosti za nakup pelet in njihovo najvišjo ceno je bila uporabljena kontingenčna metoda. Rezultati regresijskega Tobit modela so pokazali, da so parametri kot so gospodar, cena ob anketi uporabljenih gnojil in velikost kmetije pozitivno vplivali na pripravljenost za nakup pelet medtem, ko je poprejšnja uporaba organskih gnojil nanj vplivala negativno.

Ključne besede: gnojilne pelete iz fekalij; pripravljenost za nakup; Tobit regresijski model; Gana

\section{INTRODUCTION}

Food prices have been on the increase and this is attributed mainly to increases in prices of inputs, such as land, machinery, feed and chemical fertilizers. Conventional chemical fertilizers, although having the potential of polluting surface and ground water, have become more expensive. With agriculture becoming more dependent on conventional fertilizers due to loss of soil fertility and scarce land, stakeholders have sorted to find alternatives that are ecofriendly, cheaper and more productive (Mariwah \& Drangert, 2011).

Organic fertilizers have become the main alternative due to their significant agricultural, health and environmental benefits and the premium price received when organic produce are sold. Most often, the use of organic fertilizers lead to improved microbial activity and soil structure and are slow release fertilizers. Organic fertilizers are produced from plant, animal and human waste. Human waste consists of urine and faecal matter. Millions of tons of faecal matter is generated each day worldwide and are collected as faecal sludge, which could be a major resource for the production of organic fertilizers. In urban and peri-urban Areas in sub Saharan Africa (SSA), organic waste is normally not seen as a resource and hence it is collected and dumped in the sea and landfill sites (Hofny-Collins, 2006).

Municipal authorities have over the years regarded waste recycling as a low yielding and high risk business venture, hence in West Africa, these authorities focused

\footnotetext{
a Agribusiness Management/Agricultural Systems and Engineering; School of Environment, Resources and Development, Asian Institute of Technology, Pathum Thani 12120, Thailand

b Department of Agricultural Economics and Agribusiness, University of Ghana, P.O. Box LG 68 Legon-Accra, Ghana

c International Water Management Institute, Accra, Ghana
} 
on waste collection and disposal (Danso et al, 2006). Human excreta are common urban wastes and could be used as fertilizers especially for urban and peri-urban agriculture (Cofie, 2009). In some countries like China, Japan and Sweden, excreta have served as fertilizers traditionally. However, consumers of vegetables cultivated with raw excreta in Vietnam risk diseases caused mainly by parasites such as Ascaris spp. and Trichuris spp. (Phuc et al., 2006). These concerns worsened with the growth in urbanization and industrialization, or modernization, and a majority of farmers worldwide now depend mainly on chemical fertilizers as their main soil input.

With worsening faecal waste management issues, expensive and environmentally detrimental disposal methods coupled with the clarion call for sustainability in the use of natural resources, there is a shift to more adaptive and mitigating approaches to waste disposal. Now cities are looking for ways of sustainable waste management, hence a return to the human nutrient cycle. In the effort to reduce pathogen levels and make human excreta more presentable as fertilizers, various products have been developed. These include treated compost sludge, dried sludge and excreta pellets. Excreta pellets were developed not just as a way of decreasing pathogen levels but also to reduce water levels thereby solving the problem of bulkiness.

The use of dried pellets leads to a decrease in volume of $50 \%-80 \%$ of the fertilizer required on the field. Applications of such products (faecal sludge) have remained on a low or pilot scale and its performance in the field is virtually unknown to farmers. Farmers in Europe would use fertilizers derived from waste but were not willing to pay a higher price, whilst those in Thailand and Japan were relatively more willing to pay a higher price (Harris et al, 2001). Most projects involving the recycling of waste have failed due to the over reliance on the technological aspect with little or no attention on social and marketing aspects (Zurbrügg et al., 2005). Some religious and cultural beliefs also serve as constraints to marketing of a product such as excreta pellets fertilizers. It is imperative therefore to study and recognize the decision making process of end users as this will help in identifying attitudes, barriers, reactions to incentive and finally their motivation to accept a new product. The general opinion that excreta pellets are a good source of much needed plant nutrients is good. However, the factors of successful introduction of such product needs to be better understood. The objectives of the study were twofold. First, to determine the amount that farmers were willing to pay (per $50 \mathrm{~kg}$ bag). Second, to determine the factors influencing the amount that farmers were willing to pay.

\subsection{Production of excreta pellets}

The production of pelleted excreta begins with dewatered faecal sludge (DFS). Faecal sludge is received from vehicle (tanker) operators, who discharge the sludge on a sand filter for drying. After at least 15 days of sun drying and sand filtering, dewatered faecal sludge is produced. The DFS is in the form of lumps as shown in Figure It is usually packed in polypropylene bags and transported to the composting site.

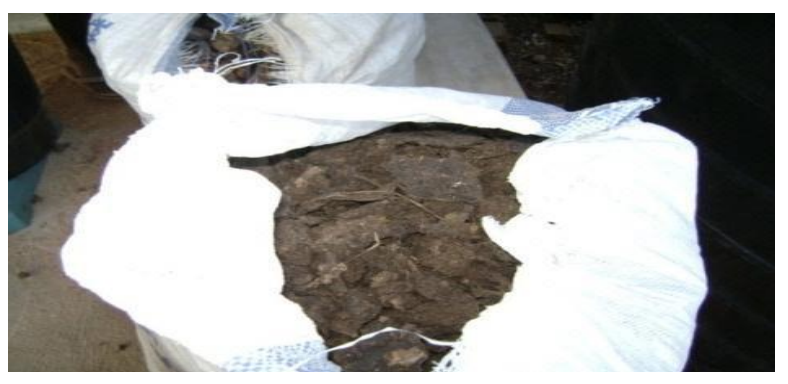

Figure 1: A bag of packed dewatered faecal sludge; source: Nikiema et al., 2013

The first step of the composting process is to manually break the DFS lumps into smaller particles, then add the required amount of water to reach a moisture content of about $65 \%$ and to finally form the heap $(0.87 \mathrm{~m}$ in height and $2.8 \mathrm{~m}$ in diameter). The moisture content is increased and a heap formed to aid in anaerobic respiration by microbes. Temperature is monitored daily while turning the heap with a spade or shovel, and moistening (to maintain moisture content of $65 \%$ ) for about 60 days. The heap is then levelled by spreading it on a platform to be sun dried, hence reducing its moisture content to less than $10 \%$. The dried composted DFS is grinded to produce a powder. The total organic carbon, nitrogen, phosphorus and potassium concentrations in the compost are then analyzed.

The pre-gelatinization process involves combining the required amounts of water with dry starch to form a paste. This paste, composted DFS and ammonium sulfate which is added for nutrient enrichment is then mixed up and put into the pelletizer to produce the 
pellets (Figure 2). The figure shows freshly produced pellets, which will undergo sun drying before being packed into sacks of $50 \mathrm{~kg}$ each. Microbiological characteristics of the dry pellets produced are then analyzed; this is done by checking if E. coli $\mathrm{T}$. Escherich, 1885 concentrations do not exceed the threshold given in the WHO guidelines (103 CFU/g of pellet) average concentrations of total coliforms being around $824 \pm 511$. The $\mathrm{CFU}$ refers to the colonyforming units.

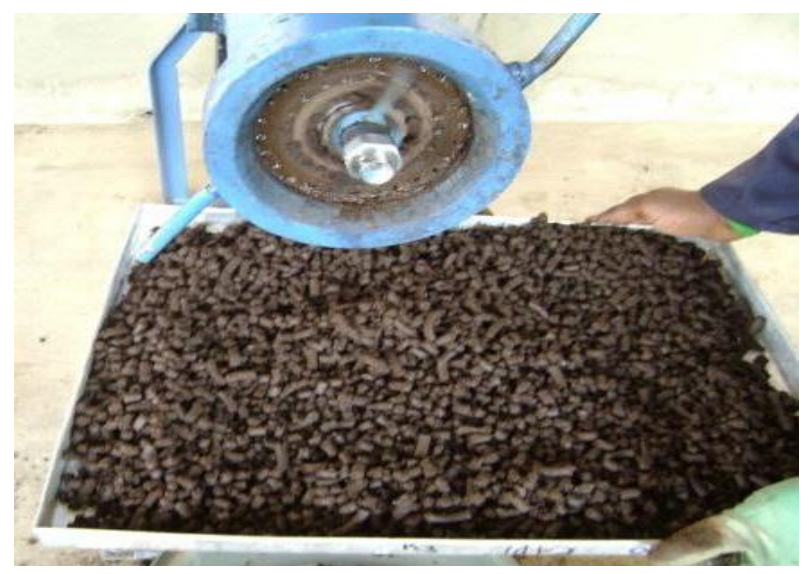

Figure 2: Freshly produced excreta pellets; source: Nikiema et al., 2013

\section{MATERIALS AND METHODS}

\subsection{Data}

The study used primary data from 461 respondents in 10 districts in Western and Greater Accra regions of Ghana. Questionnaires were administered to farmers in a face to face interview ${ }^{1}$. The questionnaire was divided into four parts with the first part focusing on the socioeconomic characteristics of the respondent. The next part was on the history of fertilizer purchases which included the number of bags used in the previous year, cost per unit, preferred form, amongst others. The third part addressed perception of previous fertilizer purchases and faecal based fertilizer. Respondents had the opportunity to indicate their agreement using a five point Likert scale on issues ranging from labelling, packaging, certification, and religious and cultural beliefs. The final part focused on the 'maximum amount they were willing to pay'. The procedure by which the data was collected from the respondents is presented as follows. A sample of the excreta pellet was shown to the respondent then the production process was explained with emphasis on the main ingredient being human excreta $^{2}$. Afterwards, the agronomical and environmental benefits were explained to the respondent. The respondent was then asked if he/she would use such a product with a positive answer leading to the following question: "are you willing to pay"? A response in the affirmative then led to the respondent rolling a dice to randomly choose one of the three starting bids. Each respondent was asked if he/she was willing to pay the first bid. If he/she said 'yes' to the first bid, a second higher bid was given and willingness to pay was asked. A 'yes' or 'no' answer to the second bid led to the last follow-up question which was the maximum he/she was willing to pay. If a respondent said 'no' to the initial bid, a second lower bid was provided. If the respondent said 'no' or 'yes' to the second lower bid, he/she was asked to mention the maximum that he/she was willing to pay $^{3}$.

1 The respondents include food crop farmers such as maize, vegetables, fruits and rice, non-food crop farmers like cocoa and flowers. Please note that the terms end users, farmers and respondents are used interchangeably in this paper.

2 Please note that the terms 'excreta pellets' and 'faecal sludge-based fertilizer' are used interchangeably in this paper.

3 The three opening bids were classified as low [GHS 15.00 (\$ 6.33)], medium [GHS 18.00 (\$ 7. 59)] and high [GHS 22.00 (\$9.28)]. The opening bid for each respondent followed a random process. In this respect, a die was rolled for each respondent to enable the choice of the starting (opening) bid. This procedure was followed to eliminate starting point bias. Please note that 1 USD $=$ GHS 2.37 when the data was collected in January, 2014. 


\subsection{Determinants of willingness to pay (wtp) amount for excreta pellet fertilizer}

The Tobit model (1958) was employed to show the relationship between the observed maximum 'willingness to pay' amount (MWTP) and explanatory variables specified in equations (1), (2), and (3) as follows:

$$
\begin{aligned}
& \operatorname{MWTP}_{i}^{*}=\alpha+\beta X_{i}^{\prime}+\varepsilon_{i} \\
& M_{W T P_{i}}=M_{W T P_{i}^{*}} \text { if } M W T P_{i}^{*}>0 \\
& M_{W T P_{i}}=0 \text { if } M W T P_{i}^{*} \leq 0
\end{aligned}
$$

where $M W T P i *$ is the end user's (farmer's) unobserved 'maximum willingness to pay' amount for the excreta pellets; $M W T P i$ is an end user's (farmer's) actual 'maximum willingness to pay amount' for the excreta pellets; $X_{i}^{\prime}$ is vector of explanatory variables; $\beta$ is vector of unknown true coefficients; $\alpha$ is the intercept; and $\varepsilon_{\mathrm{i}}$ is disturbance term, which is assumed to be normally independently distributed, i.e., NID $\left(0, \sigma^{2}\right)$ and independent of $x_{i}$. Assuming that the variable is zero, then the dependent variable in the Tobit regression model is a continuous variable (i.e. the maximum amount quoted by end users to pay for $50 \mathrm{~kg}$ excreta pellets as fertilizer). The amount end users were willing to pay was hypothesized to be influenced by the following factors:

Age of the Respondent (AGE): This is a continuous variable indicating the age of the respondent in years. The age of respondent may have either negative or positive effect on WTP decision. Aged farmers may not see the need for long term sustainability of soil fertility and may be conservative to new ideas hence may show negative attitude towards the faecal sludge fertilizer. On the other hand, as they grow much older, they may become more experienced thereby willing to conserve the soil through the use of excreta pellets and hence positively influencing their WTP decision (Tessema \& Holden 2006; Asgary et al., 2004; Dong et al., 2003).

Experience (EXP): Farming experience leads to increased willingness to improve the soil for better productivity (Tessema \& Holden, 2006). Hence experience is expected to positively influence WTP decision.

Education Level of the Respondent (EDUCATION): This parameter refers to the number of years that the respondent has spent in a formal school. Following Paulos (2002) and Yitayal (2004), the study assumed that respondents who had high level of education better understood the problems of soil erosion or degradation and its consequences and therefore would be willing to invest in a product that increases fertility and conservation of the soil.

Household Head (HHD): This is a dummy variable which takes a value of 1 if the respondent is the head of the household; and 0 otherwise. It is hypothesized that being a household head is expected to influence willingness to pay positively.

Household Size (HSIZE): This is a continuous variable which refers to the number of family members in the household. This explanatory variable is included because it affects the labor supply at the household level. Also, households with more people to feed will be willing to pay for a new input that would increase yield (Agyekum et al., 2014).

Gender of the Respondent (Gender): dummy variable ( $1=$ male, $0=$ otherwise $)$ and is included in the model to find out the influence of gender on WTP. Males have a probability of getting better access to information than females. Therefore, a positive influence is hypothesized for male respondent. Female farmers tend to adopt new technologies at a lower rate than males due to seemingly limited access to information and resource (Doss \& Morris, 2001).

Farm Size (Farmsize): It is a continuous variable expressed in terms of hectares of cultivated land and expected to have a positive effect on the willingness to pay. This is expected because farmers (end users) with larger land size tend to be commercially oriented and hence would invest in an input that will positively affect production (Oladele, 2008; Cofie, 2010).

Farm Income (FARMINC): This is a continuous variable. It is measured as the annual farm income from sale of produce. It is expected to have a positive relationship with WTP. As income increases it positively affects the WTP for waste as fertilizer. This can be linked to farmers having more money to afford such a product. Numerous empirical studies have reported positive relationships between income and adoption of agricultural technologies and input (Faye \& Deininger, 2005; Holden \& Shiferaw, 2002;

Mbata, 2008).

Aware of Faecal Fertilizer (Aware): This is a dummy variable which assumes 1 for "yes I am aware of faecal fertilizers", and 0 otherwise. It is hypothesized that respondents who have prior knowledge of faecal sludgebased fertilizer would be more willing to use excreta pellets since they are less bulky and the unpleasant smell is removed. Also, farmers who were aware of 
other available agricultural inputs were more receptive to paying for these inputs (Asrat et al., 2004).

\section{Quantity of Fertilizer Previously Used (Number of $50 \mathrm{~kg}$ bags): A continuous variable that measures the amount of fertilizer used in the previous year. A unit was pegged at $50 \mathrm{~kg}$ bag based on the fact that the majority of the respondents bought fertilizers packaged in $50 \mathrm{~kg}$ bags. It is hypothesized that an increase in the quantity used will increase the probability of end users WTP.}

Unit Cost (unit cost): This is a continuous variable that measures the average cost of a unit $(50 \mathrm{~kg} \mathrm{bag})$ of fertilizer used in the previous year. It is hypothesized that an increase in price of the cost of fertilizer would lead to an increase in the probability of WTP.

Previous Use of Organic Fertilizer (Used Organic): This is a dummy variable that assumes 1 for "yes I have ever used organic fertilizer" and 0 otherwise. It was hypothesized that previous use of organic fertilizer would positively influence the end users WTP decision.

Membership of Farmer Based Organization (member of FBO): This is a dummy variable which assumes 1 for "yes I am a member" and 0 for otherwise. It is hypothesized that being a member of a farmerbased organization (FBO) will positively affect the WTP amount.

Own Current Land (own land): This is a dummy variable which assumes 1 for "yes I own the land that am currently working on" and 0 for otherwise. Following Obuobie et al., (2006), a positive relation with maximum WTP amount is hypothesized. The previous study revealed that most farmers on hired land were not allowed by the land owners to use faecal sludge based fertilizer in the city of Tamale in the northern region of Ghana.

\section{RESULTS AND DISCUSSION}

\subsection{Preliminary results}

The study found that about $69 \%$ of the farmers interviewed were aware of excreta pellets as fertilizer whilst $31 \%$ of the total respondents were not aware. This indicates that the use of faecal sludge as fertilizer is not an alien concept to farmers. The farmers agreed with the assertion that fertilizer derived from human excreta should be certified by a relevant body such as the Environmental Protection Agency (EPA) before its introduction onto the market, and that certification by a relevant authority would lead to increased willingness to pay for excreta pellet fertilizer. Farmers also agreed that excreta pellets can be used as a replacement for conventional chemical fertilizers. Farmers in northern Ghana disclosed that human excreta when used in farming produce better and safer yields (i.e. enhance agricultural productivity) than conventional fertilizers, hence it should be used in place of the conventional fertilizers (Kranjac-Berisavljević, 2009). Farmers perceived that such a fertilizer has a positive effect on long term fertility of soils. With regard to health, farmers did not agree that using faecal-based fertilizer would expose them to several major health risks. However, they did indicate that use of raw or untreated human excreta on farmland is associated with some skin infections, diarrhea, foot rot and vomiting. The majority of respondents interviewed $(91.1 \%)$ claimed that they would not buy excreta pellets if it is sold at the same price as conventional fertilizer. However, they would buy excreta pellets if cheaper than conventional chemical fertilizers; in other words, they expect the price of the product to be lower than the price of conventional chemical fertilizers (Cofie et al, 2009).

Majority of respondents that indicated their WTP for excreta pellets, only $29 \%$ stated they were not willing to pay. The reasons stated were: those excreta pellets have not been certified for use by farmers, especially under global GAP; and that some farmers also claimed that excreta pellets need to be tested on their produce before they would be willing to buy. One of the reasons for not willing to pay was that the product was not certified and not tested in their locality to ascertain its quality. Some were also of the view that since the product is made from human excreta which are waste coupled with disposal being a major problem to local authorities, it should not be sold. In general, over $70 \%$ of respondents were willing to pay for excreta pellets as fertilizer and this level of approval is consistent with previous studies (Danso et al. 2006, and Agyekum et al. 2014).

Table 1 shows the distribution of the willingness to pay amounts by the respondents. ${ }^{4}$ Nine respondents (representing $2.6 \%$ ) were willing to pay less than GHS 10.00 [\$4.22] for a $50 \mathrm{~kg}$ bag of the excreta pellets. Forty eight respondents (representing $14 \%$ ) were willing to pay between GHS 10.00 and GHS 19.99 [\$ 4.22 - \$ 8.43]. Also, one hundred and ninety seven respondents (representing $57.6 \%$ ) were willing to pay between GHS 20.00 and GHS 29.99 [\$ $8.44-\$ 12.65]$.

4 Please note that 342 respondents out of the total sample of 461 were willing to pay for the excreta pellets. 
Seventy seven respondents (representing about $22.5 \%$ ) were willing to pay between GHS 30.00 and GHS 39.99 [ $\$ 12.66-\$ 16.87]$, and eleven respondents (representing about $3.2 \%$ ) were willing to pay GHS 40.00 and GHS 50.00 [\$ 16.88 - \$ 21.10].

Table 1: Maximum willingness to pay amount

\begin{tabular}{lll}
\hline WTPA & Frequency & Percentage \\
\hline$<10$ & 9 & 2.6 \\
$10-19.99$ & 48 & 14.0 \\
$20-29.99$ & 197 & 57.6 \\
$30-39.99$ & 77 & 22.5 \\
$40-50$ & 11 & 3.2 \\
\hline Total & 342 & 100 \\
\hline
\end{tabular}

\subsection{Tobit regression model results of the factors influencing willingness to pay maximum amount}

The minimum price per $50 \mathrm{~kg}$ bag quoted was GHS 2.00 [\$ 0.84] and a maximum of GHS 50.00 [\$21.10]. The mean price quoted was GHS 22.83 [\$ 9.63]. This mean amount was quite higher than that quoted by respondents in Agyekum et al. (2014) for $50 \mathrm{~kg}$ of faecal compost. The Tobit regression model results of the factors that influenced willingness to pay amounts quoted by the farmers are presented in Table 2. Being a household head was significant and had a positive relation with the willingness to pay. A household head was willing to pay GHS 5.12 [\$ 2.16] more for a bag of excreta pellets compared to an end user who is not the head of the household. This willingness to pay more for such an input may be due to the responsibilities associated with such a position that would make the farmer want to invest in soil conservation (Gebremedin, 2012). Farm size was also significant and positively influenced WTP amount, as farm size increased by a hectare, the WTP amount increased by GHS 0.48 [\$ $0.20]$. This could be due to high cost of use of inorganic fertilizer, as farm size increases end users would be more willing to use faecal sludge-based fertilizers. End users with larger farm size would also be willing to pay more for excreta pellets because as stated by Oladele (2008) they are commercially oriented and hence would like to invest in an input that will impact positively on production. The results also revealed a negative and significant relation between the amounts an end user was willing to pay and if he had ever used an organic fertilizer. Thus, if the end user has ever used organic fertilizer, he was willing to pay GHS 2.41 [\$ 1.02] less for the $50 \mathrm{~kg}$ of the excreta pellets compared to a respondent who has never used organic fertilizer. This relation could be attributed to the cheaper prices of organic fertilizer available as some farmers acquired organic fertilizers for free and are only required to pay for the transportation cost. Hence, this category of farmers will not be willing to pay a high price for another organic product. This assertion is consistent with previous studies in which farmers with compost or manure experience were willing to pay less for faecal compost (Drechsel et al. 2004, Danso et al. 2006). Also, if organic fertilizer were available, use by farmers may be very low due to limited knowledge and management among farmers (Obour et al., 2015).

As expected, there is a positive relation between willingness to pay amount and the average unit cost of fertilizer currently being used by the end user. A GHS 1 increase in the unit cost of the current fertilizer being used will lead to paying GHS 0.06 [\$ 0.03] more for excreta pellets (though negligible). This can be attributed to an end user looking to invest in cheaper alternatives. 
Table 2: Tobit regression results of the factors influencing maximum willingness to pay amount

\begin{tabular}{lll}
\hline Variable & Coefficient & P>t \\
\hline Gender & -2.160 & 0.147 \\
Age & 0.030 & 0.608 \\
Household Head & $5.119 * * *$ & 0.001 \\
Household Size & 0.050 & 0.813 \\
Own Land & -0.146 & 0.903 \\
Used Organic & $-2.406^{* *}$ & 0.030 \\
No Of 50 kg & -0.006 & 0.271 \\
Unit Cost & $0.040^{* * *}$ & 0.022 \\
Farm Size & $0.480^{* *}$ & 0.024 \\
Income & 0.000 & 0.376 \\
Education & -0.058 & 0.660 \\
FBO Member & 1.731 & 0.147 \\
Experience & -0.050 & 0.405 \\
Aware Of Faecal Fertilizer & 1.183 & 0.309 \\
Constant & 11.969 & 0.000 \\
\hline Number of obs & & 459 \\
F(14, 445) & & 2.800 \\
Prob F F & & 0.001 \\
Pseudo R2 & & 0.001 \\
Log pseudolikelihood & & -1770.3 \\
\hline
\end{tabular}

$*, * *$ and $* * *$ denotes $10 \%, 5 \%$ and $1 \%$ significant level

\section{CONCLUSIONS AND IMPLICATIONS}

The results of this study revealed that the perceptions about fertilizer derived from human excreta are positive. Majority of respondents did not have religious, health and cultural hindrances to the use of excreta product. They described excreta pellet as a potentially good replacement for conventional fertilizer. Respondents also indicated that they would use a faecal sludge-based fertilizer provided it was certified by the Environmental Protection Agency since this certification and labeling would lead to trust in the product. Interestingly, almost all respondents indicated that they would not purchase excreta pellet if it is sold at the same price as conventional chemical fertilizer. However, these respondents mentioned that they would purchase the excreta pellet if it is sold cheaper than the conventional chemical fertilizers on the market. There is a potential for the marketing of excreta pellet as fertilizer in Ghana. Producers of different backgrounds were interested in using the product for both crop and non-crop agricultural enterprises as they expressed positive perception about the product. End users were willing to pay a minimum of GHS 2.00 [\$0.84], a maximum of GHS 50.00 [\$ 21.10] and a mean of GHS 22.83 [\$9.63]. to obtain a $50 \mathrm{~kg}$ bag of excreta pellet fertilizer. The results of the Tobit regression model revealed that being a household head, unit cost of current fertilizer used, and farm size positively influenced the willingness to pay amount whereas previous use of organic fertilizer influenced the willingness to pay amount negatively. Thus, the marketing of excreta pellet as fertilizer has prospects in Ghana. End users are interested in reducing cost hence would welcome any input that is cheaper and effective. Based on these findings, this paper recommends that marketing of faecal sludge based fertilizer should target people in decision making positions such as household heads with large farm sizes and businesses in the manufacturing sector of Ghana should find innovative ways of reducing the cost of production of excreta pellet fertilizer so as to reduce the price when offered on the market. A cheaper product will be wholly accepted by end users. The Ghana Standards Authority should support manufacturing companies to satisfy certification requirements of the product before introduction onto the market. Demonstration plots should be identified at the district level so as to give first hand education on the use of the product. For florists, the product should be tested on their flowers to dispel the notion that it might be too strong for the plants and may cause wilting. Also a protocol or brochure should be added to the product (when sold), indicating how product should be applied to meet specific crop or plant nutrients requirements. Marketing of the product should target farmer-based organizations, people in social positions such as household heads and people with larger land holdings. Information about the efficacy of product will flow to other end users. Government institutions such as Environmental Protection Agency (EPA), Council for 
Industrial and Scientific Research (CSIR) and the Ministry of Food and Agriculture (MoFA) should establish clear guidelines and standards on the use of faecal sludge-based fertilizers. When establishing quality guidelines, the institutional capacities for controlling and enforcing them should also be taken into account. More importantly, political will and legal tools should be adequate enough to enforce quality standards. This will go a long way to help maintain end users' confidence in the product for the long term since the raw material is inexhaustible. MoFA must intensify its education on the use of protective clothing especially gloves when applying the excreta pellet fertilizer.

\section{ACKNOWLEDGEMENTS}

The authors gratefully thank International Water Management Institute, Accra, Ghana for providing funding for this study. The authors also thank the respondents for their answers and time.

\section{REFERENCES}

Agyekum, E. O., Ohene-yankyera, K., Keraita, B., Fialor, S. C. \& Abaidoo, R. C. (2014). Willingness to Pay for Faecal Compost by Farmers in Southern Ghana. Journal of Economics and Sustainable Development 5(2), 18-25.

Asgary, A., K.Willis, A. A. Taghvaei, and M. Rafeian (2004). 'Estimating rural households' willingness to pay for health insurance', European Journal of Health Economics. 5.209-215.

Asrat, P., K. Belay, and D. Hamito. 2004. Determinants of farmers' willingness to pay for Soil Conservation Practices in the Southeastern Highlands of Ethiopia. Land Degradation and Development, 15, 423-438. doi:10.1002/ldr.623

Cofie O. \& Adamtey N., (2009). Nutrient Recovery from Human Excreta for urban and peri-urban Agriculture. Contribution to SuSanA Food Security Working Group meeting during the WEDC international conference in Addis Ababa, Ethiopia. April 152009.

Cofie, O., Adeoti, A., Nkansah-boadu, F., \& Awuah, E. (2010). Resources , Conservation and Recycling Farmers perception and economic benefits of excreta use in southern Ghana. Resources, Conservation \& Recycling, 55(2), 161166. doi:10.1016/j.resconrec.2010.09.002

Danso, G., Drechsel, P. Fialor, S. and Giodano, M. (2006). Estimating the demand for municipal waste compost via farmers' willingness-to-pay in Ghana. Waste Management Journal, 26(12), 1400-9. doi:10.1016/j.wasman.2005.09.021

Dong, H., B. Kouyate, J. Cairns, F. Mugisha and R. Sauerborn (2003). 'Willingnessto pay for community based insurance in Burkina Faso. Health Economics, 12(10), 849-862. doi:10.1002/hec.771
Doss, C. R., \& Morris, M. L. (2001). How does gender affect the adoption of agricultural innovations: The case of improved maize technology in Ghana. Agricultural Economics, 25, 27-39. doi:10.1016/S0169-5150(00)00096-7

Drechsel P, Cofie O, Fink M, Danso G, Zakari F, \& Vasquez R. (2004). Closing the rural-urban nutrient cycle. Options for municipal waste composting in Ghana. Final scientific report on IDRC project 100376, IWMI-West Africa, Accra.

Escherich, T. (1885). Ueber die bacterien des milchkothes, Artz Intelligenz-Blatt, Mün Med Wcsht, 32, pg. 243.

Escherich, T. (1885). Die darmbakterien des neugeborenen und säuglings, Fortsch der Med, 3, (pg. 515-22) 547-54.

Foti R, Nyakudya I, Moyo M, Chikuvire J, \& Mlambo N. (2007). Determinants of Farmer Demand for "Fee-for-Service Extension in Zimbabwe: The Case of Mashonaland Central Province. Journal of International Agricultural and Extension Education, $\quad 14 \quad$ (1), 95-104. doi:10.5191/jiaee.2007.14108

Faye, I., \& Deininger K. (2005). Do New Delivery Systems Improve Extension Access? Evidence from Rural Uganda. Paper presented at the American Agricultural Economics Association Annual Meeting, July 24-27, Providence, RI, US.

Gebremedin, G. (2012). Households' willingness to pay for soil conservation practices in Adwa Woreda, Ethiopia: A Contingent Valuation Study. A Thesis Submitted To The Faculty Of Development Studies In Partial Fulfilment For The Requirements Of Masters of Science Degree In Agricultural and Applied Economics, University Of Malawi. 
Harris, P.J.C., Allison, M., Smith, G., Kindness, H.M. \& Kelly, J. (2001). 'The Potential Use of Waste Streams. Products for Soil Amelioration in Periurban Interface Agricultural Production Systems', in Pay Drechsel and Agmar Kunze (eds), Waste Composting for Urban and Peri-irban Agriculture: Closing the Rural-Urban Nutrient Cycle in SubSaharan Africa, CABI Publishing, Wallingford, Oxon, UK, pp. 1-28. doi:10.1079/9780851995489.0001

Hofny-Collins A. (2006) The Potential for Using Composted Municipal Waste in Agriculture: The case of Accra, Ghana. Doctoral thesis Swedish University of Agricultural Sciences Uppsala 2006. Acta Universitatis agriculturae Sueciae, 65, 16526880.

Holden, S. T., and B. Shiferaw. (2002). "Poverty and Land Degradation: Peasants' Willingness to Pay to Sustain Land Productivity." In The Adoption of Natural Resource Management Practices: Improving Sustainable Agricultural Production in Sub-Saharan Africa, edited by. C. B. Barrett, F. M. Place, and A. A. Aboud, 91-102. New York: CABI Publishing. doi:10.1079/9780851995847.0091

Kranjac-Berisavljevic G., (2009). Use of Faecal Sludge for Agriculture in Tamale Metropolis: perception of Farmers, Consumers and Relevant Agencies. Presentation from the 2009 World Water Week.

Mariwah, S., \& Drangert, J.-O. (2011). Community perceptions of human excreta as fertilizer in periurban agriculture in Ghana. Waste Management \& Research, $0(0)$

$1-8$. doi:10.1177/0734242x10390073

Mbata, G. I. O. (2008). Determinants of profitability and willingness to pay for metropolitan waste-use in urban agriculture of The Federal Capital Territory, Abuja , Nigeria Federal Capital Territory Agricultural Development Programme, Gwagwalada , Abuja. Journal of Tropical Agriculture, Food, Environment and Extension, 7(1), 41-46.

Nikiema J., Cofie O., Impraim R., \& Drechsel P. (2012). Fortified Excreta Pellets for Agriculture. International Water Management Institute - West Africa Office, www.iwmi.org.

Obour, P. B., Dadzie, F. A., Kristensen, H.L., Rubæk, G. H., Kjeldsen, C., \& Saba, C. K. S. (2015).
Assessment of farmers' knowledge on fertilizer usage for peri-urban vegetable production in the Sunyani Municipality, Ghana. Resources, Conservation \& Recycling, 103, 77-84. doi:10.1016/j.resconrec.2015.07.018

Obuobie, E., Keraita, B., Danso, G., Amoah, P., Cofie, O., Rachid-Sally, L. \& Drechsel, P. (2006). Irrigated Urban Vegetable Production in Ghana. Characteristics, Benefits and Risks. CSIR-INST Accra, Ghana. Pp.70-98.

Oladele, O. I. (2008). Factors Determining Farmers' Willingness To Pay For Extension Services In Oyo State, Nigeria. Agricultura Tropica Et Subtropica, 41(4), 165-170.

Paulos, A. (2002). Determinants of Farmers" Willingness to Participate in Soil Conservation Practices in the Highlands of Bale: The case of Dinsho farming system area. MSc. Thesis, Alemaya University. Haramaya, Ethiopia.

Phuc, P. D., Konradsen, F., Phuong, P. T., Cam, P. D., \& Dalsgaard, a. (2006). Practice of using human excreta as fertilizer and implications for health in Nghean Province, Vietnam. The Southeast Asian journal of tropical medicine and public health, 37(1), 222-9. Retrieved from http://www.ncbi.nlm.nih.gov/pubmed/16771238.

Tessema, W., \& Holden, S. (2006). Soil Degradation, Poverty, and Farmers ${ }^{e e}$ Willingness to Invest in Soil Conservation: A case from a Highland in Southern Ethiopia. Ethiopian Economic Association, Proceedings of the Third International Conference on the Ethiopian Economy, Vol. 2, pp 147- 164.

Tobin, J. (1958). Estimation of relationships for limited dependent variables. Econometrica, 26 (1), 24-36. doi: $10.2307 / 1907382$

Yitayal, A. (2004). Determinant of Use of Soil Conservation Measures by Small Holder Farmers; in Gimma Zone, Dedo District. An MSc Thesis Presented to School of Graduate Studies of Alemaya Universtity.

Zurbrügg, C., Drescher, S., Rytz, I., Sinha, A. H. M. M., \& Enayetullah, I. (2005). Decentralised composting in Bangladesh, a win-win situation for all stakeholders. Resources, Conservation and Recycling, 43(3), 281-292. doi:10.1016/j.resconrec.2004.06.005 